\title{
Recent advances in neuromuscular block during anesthesia
}

\section{[version 1; peer review: 4 approved]}

\author{
Martijn Boon (iD), Christian Martini, Albert Dahan (ib) \\ Department of Anesthesiology, Leiden University Medical Center, Leiden, The Netherlands
}

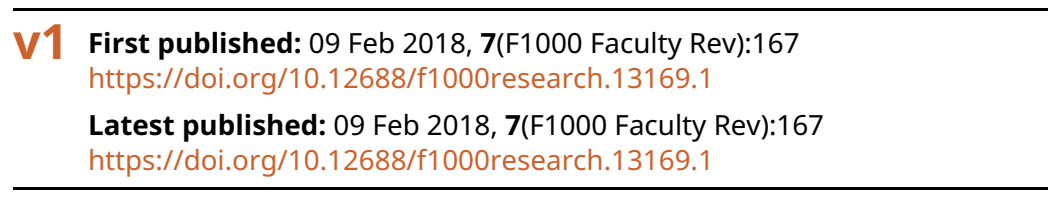

\section{Abstract}

Muscle relaxation is a routine part of anesthesia and has important advantages. However, the lingering effects of muscle relaxants in the postoperative period have historically been associated with postoperative adverse events. Neuromuscular reversal, together with neuromuscular monitoring, is a recognized strategy to reduce the rate of postoperative residual relaxation but has only marginally improved outcome in the past few decades.

Sugammadex, a novel reversal agent with unique encapsulating properties, has changed the landscape of neuromuscular reversal and opened up new opportunities to improve patient care. By quickly and completely reversing any depth of neuromuscular block, it may reduce the rate of residual relaxation and improve respiratory recovery. In addition, sugammadex has made the use of deep neuromuscular block possible during surgery. Deep neuromuscular block may improve surgical working conditions and allow for a reduction in insufflation pressures during selected laparoscopic procedures. However, whether and how this may impact outcomes is not well established.

\section{Keywords}

deep neuromuscular block, sugammadex, postoperative residual curarisation, surgical rating scale

\section{Open Peer Review}

Approval Status

\begin{tabular}{lllll} 
& 1 & 2 & 3 & 4 \\
\hline version 1 & & & & \\
09 Feb 2018 & & & & \\
\hline
\end{tabular}

Faculty Reviews are review articles written by the prestigious Members of Faculty Opinions. The articles are commissioned and peer reviewed before publication to ensure that the final, published version is comprehensive and accessible. The reviewers who approved the final version are listed with their names and affiliations.

1. Thomas Mencke, University of Rostock, Rostock, Germany

2. Peter Biro, University Hospital Zurich, Zurich, Switzerland

3. Jacob Rosenberg, Herlev Hospital, University of Copenhagen, Herlev, Denmark

4. Ahmed R Ahmed, Imperial College London, London, UK

Any comments on the article can be found at the end of the article. 
Corresponding author: Martijn Boon (m.boon@lumc.nl)

Author roles: Boon M: Conceptualization, Investigation, Project Administration, Writing - Original Draft Preparation, Writing - Review \& Editing; Martini C: Conceptualization, Investigation, Project Administration, Writing - Review \& Editing; Dahan A: Conceptualization, Funding Acquisition, Investigation, Methodology, Project Administration, Supervision, Writing - Review \& Editing

Competing interests: $\mathrm{MB}, \mathrm{CHM}$, and $\mathrm{AD}$ received speaker and/or consultancy fees from Merck Sharp \& Dohme Corporation, The Netherlands BV. The laboratory of professor Dahan received grants from Merck Sharp \& Dohme Corporation BV to support investigator initiated trials.

Grant information: The author(s) declared that no grants were involved in supporting this work.

Copyright: $\odot 2018$ Boon $\mathrm{M}$ et al. This is an open access article distributed under the terms of the Creative Commons Attribution License, which permits unrestricted use, distribution, and reproduction in any medium, provided the original work is properly cited.

How to cite this article: Boon M, Martini $C$ and Dahan $A$. Recent advances in neuromuscular block during anesthesia [version 1; peer review: 4 approved] F1000Research 2018, 7(F1000 Faculty Rev):167 https://doi.org/10.12688/f1000research.13169.1

First published: 09 Feb 2018, 7(F1000 Faculty Rev):167 https://doi.org/10.12688/f1000research.13169.1 


\section{Introduction}

Muscle relaxants or neuromuscular blocking agents (NMBAs), introduced in 1942 by Griffith and Johnson, revolutionized the practice of anesthesiology ${ }^{1}$. NMBAs block neuromuscular transmission at the neuromuscular junction by binding to the postsynaptic nicotinergic acetylcholine receptor. This renders these receptors unavailable for acetylcholine-mediated neuromuscular signal transmission (see Figure 1). In practice, NMBAs enable anesthesiologists to temporarily paralyze patients during anesthesia. The introduction of NMBAs in anesthesia meant that optimal surgical conditions (i.e. by ensuring an immobile patient) could be achieved with lower doses of volatile or intravenous anesthetics, improving hemodynamic stability. Consequently, the induction of muscle relaxation became an established part of the classic anesthesia triad, alongside unconsciousness (hypnosis) and pain relief ${ }^{2}$. However, like most medication, NMBAs are not devoid of disadvantages. Lingering effects of NMBAs in the postoperative period, also known as postoperative residual curarization (PORC), may cause life-threatening respiratory complications in the first few hours after surgery ${ }^{3}$. In 1954, Beecher et al. were the first to note a sixfold increase in anesthesia-related mortality when NMBAs were used ${ }^{4}$. Despite the development of shorter-acting agents and neuromuscular monitoring techniques, NMBAs continue to be associated with severe adverse events after anesthesia, even today $^{5,6}$.

\section{Reversal of neuromuscular block}

Currently, two concepts of neuromuscular reversal exist. A moderate neuromuscular block (NMB) (see below) is traditionally reversed with an acetylcholinesterase inhibitor such as neostigmine. These drugs increase the amount of acetylcholine in the neuromuscular junction by inhibiting the enzyme acetylcholinesterase. The increased levels of acetylcholine compete with the NMBA molecules for the postsynaptic nicotine receptors (i.e. competitive antagonism) and tip the balance towards enhanced signal transmission. Encapsulation of NMBA molecules by sugammadex represents a novel reversal strategy. Sugammadex is a modified $\gamma$-cyclodextrin, which is able to selectively bind free plasma NMBA molecules (Figure 1) 7 . Encapsulation by sugammadex immediately inactivates these NMBA molecules, rendering them permanently unavailable for redistribution to the neuromuscular junction ${ }^{8}$. Sugammadex produces rapid and safe reversal of the commonly used non-depolarizing NMBAs rocuronium and vecuronium ${ }^{9,10}$. It encapsulates and consequently inactivates these NMBA molecules on a one-to-one basis and is able to reverse both moderate and deep or even intense levels of NMB (see below) ${ }^{11-13}$. Importantly, sugammadex reversal is much faster and more intense than reversal with acetylcholinesterase inhibitors ${ }^{14}$. For example, the average time for reversal of a moderate neuromuscular block is 2.7 minutes after administration of $2 \mathrm{mg} \cdot \mathrm{kg}^{-1}$ sugammadex compared to 17.9 minutes after administration of $50 \mu \mathrm{g} \cdot \mathrm{kg}^{-1}$ neostigmine ${ }^{15}$. In addition, sugammadex is well tolerated by patients and is devoid of cholinergic side effects ${ }^{14,16}$. Sugammadex has been available in Europe since 2008 and was approved by the FDA for use in the USA in 2015 .

Although the introduction of sugammadex represents a great improvement in the reversal of NMB, there are some important aspects that deserve consideration. First, only NMB induced by rocuronium, vecuronium, and pancuronium can be reversed with sugammadex, leaving acetylcholinesterase inhibitors the only choice for reversal of the other NMBAs, such as cisatracurium. In the future, new broad-spectrum encapsulating agents may become available for all NMBAs ${ }^{17}$. Second, the cost of sugammadex is significant (in the Netherlands, one ampoule of $200 \mathrm{mg}$ costs 78 euro). It is unclear whether sugammadex reversal leads

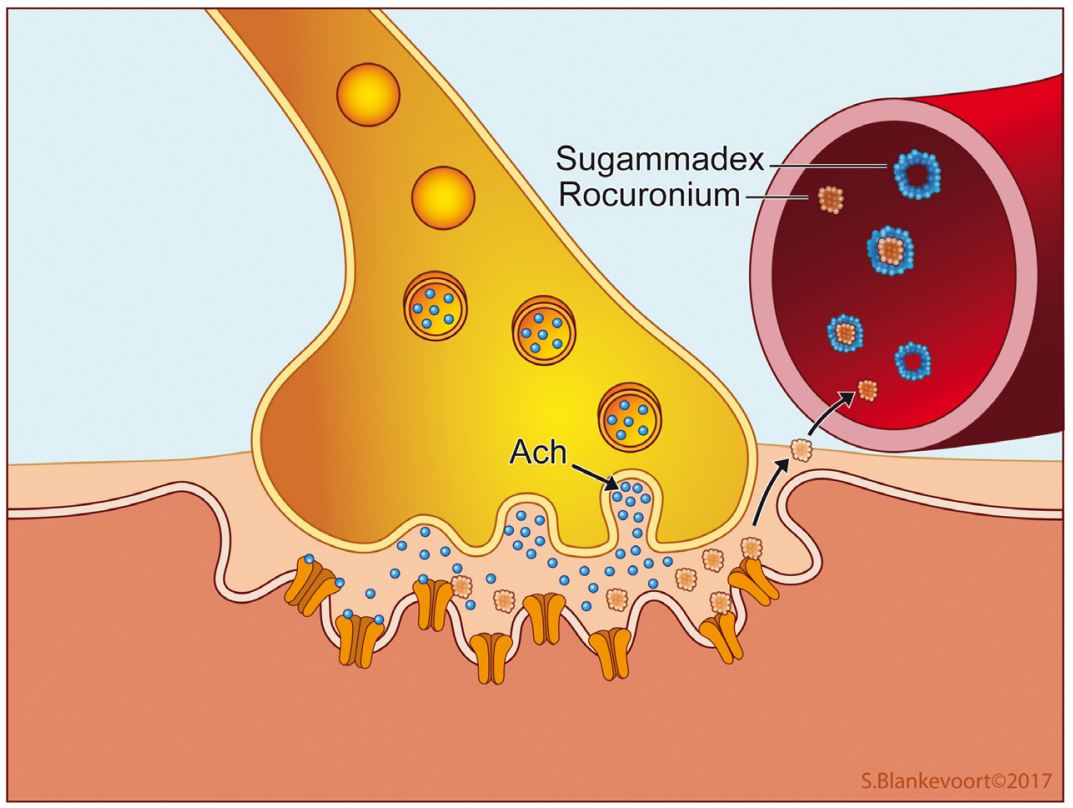

Figure 1. Neuromuscular transmission and blockage at the neuromuscular junction. Ach, acetylcholine. 
to an improved postoperative outcome that justifies its cost. The same holds true for another emerging area of interest made possible by sugammadex, which is the application of a deep NMB during anesthesia. With the introduction of sugammadex, the use of a deep NMB during surgery is now possible without the fear of prolonged recovery times. Deep NMB may improve surgical working conditions for some procedures and allows for a reduction in insufflation pressures during laparoscopic surgeries $^{18-21}$. However, the impact of deep NMB on patient outcome is still unclear.

\section{Monitoring depth of neuromuscular block}

Neuromuscular monitoring during anesthesia is most commonly performed using the train of four (TOF) method ${ }^{22}$. TOF peripheral nerve monitors (such as the TOF-Watch ${ }^{\mathrm{TM}}$ monitor) are usually applied at the distal forearm to stimulate the ulnar nerve. Here, four consecutive supramaximal electrical stimuli (a TOF) will evoke contractions (twitches) at the musculus adductor pollices of the thumb. Under normal conditions, the amplitude of all four motor responses will be equal. With an increasing degree of NMB (induced by non-depolarizing NMBAs), the amplitude of the latter twitches decreases, relative to the first twitches, a phenomenon called fade. Eventually, as NMB increases, all twitches will become absent (see Figure 2). Thus, the number of detectable thumb twitches and the degree of fading correspond with the intensity of the NMB. The degree of fading can be further expressed as a ratio, by dividing the motor response of the fourth twitch (T4) to the first twitch (T1), i.e. the T4:T1 ratio or the so-called TOF ratio. Available evidence indicates that the NMB has to be recovered to a TOF ratio of 0.9 or greater to allow for safe extubation of the patient $^{23-27}$.

When high doses of NMBAs are given, measurement of the $\mathrm{NMB}$ at the ulnar nerve will show zero thumb twitches (TOF equals zero). To measure the degree of NMB in this instance, a tetanic stimulus of $50 \mathrm{~Hz}$ for five seconds is applied to the ulnar nerve. The tetanic stimulus causes a large amount of acetylcholine to be released in the neuromuscular junction. This tetanic facilitation is subsequently followed by 15 single electrical stimuli delivered at one-second intervals. The number of measured thumb twitches make up the post tetanic count (PTC) ${ }^{28}$. For example, when six thumb twitches are observed following the tetanic facilitation, the PTC equals six (see Figure 2). With TOF and PTC measurements, the depth of the NMB can be classified as follows ${ }^{29}$ : (1) moderate NMB: TOF one to three out of four twitches; (2) deep NMB: TOF zero twitches and PTC more than zero twitches; (3) intense NMB: TOF zero and PTC zero twitches. Note that, in practice, an intense NMB is present only at the beginning of anesthesia following the induction dose of NMBA. Thereafter, NMB is allowed to recover to a deep or moderate NMB, which can be maintained to preserve adequate surgical working conditions, depending on the type of surgery.

\section{Postoperative residual curarization}

Full recovery of NMB at the end of anesthesia is essential for the return of adequate respiration and upper airway muscle function $^{3,30,31}$. By definition, PORC is present when some level
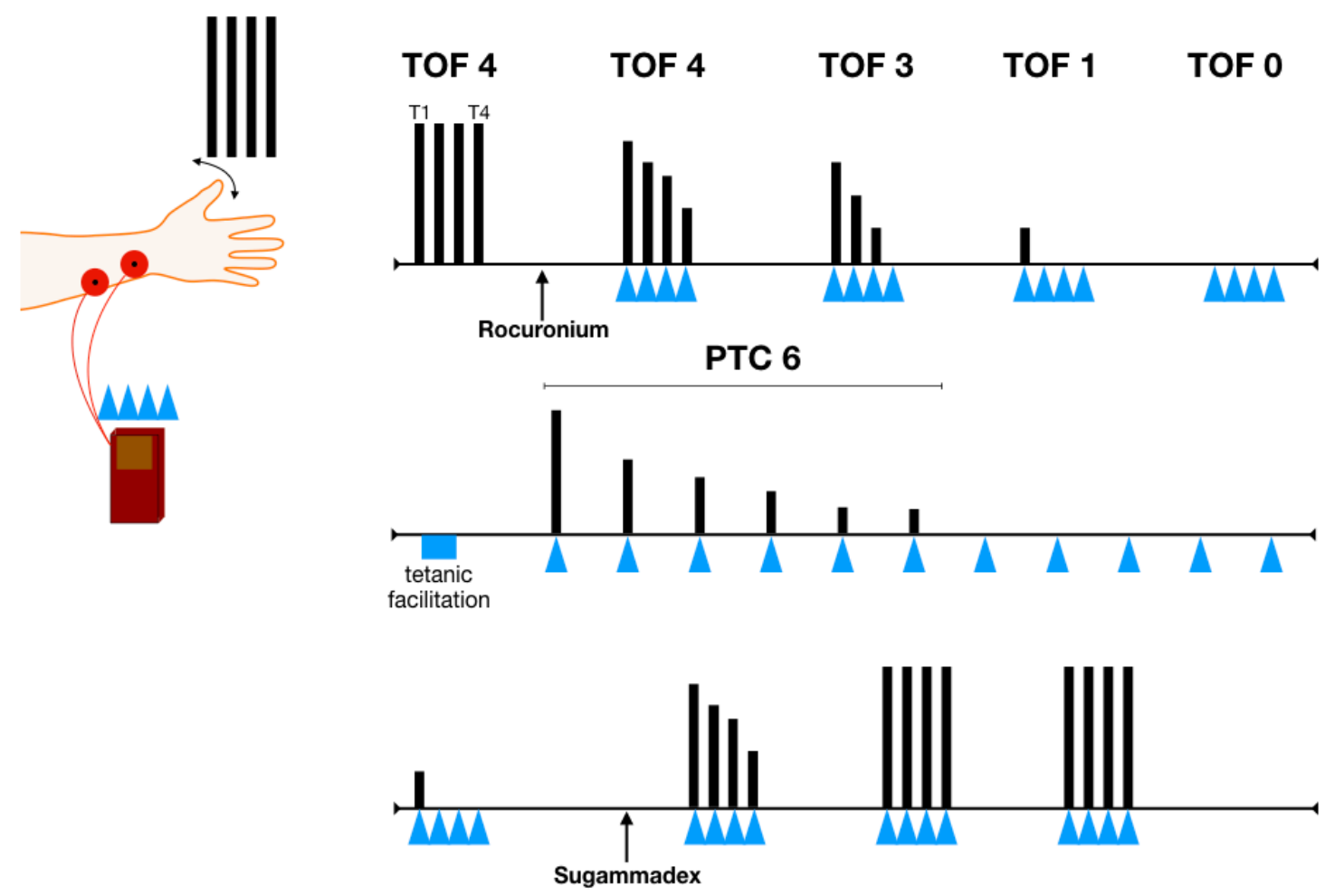

Figure 2. Neuromuscular monitoring. PTC, post tetanic count; TOF, train of four. 
of NMB (TOF ratio <0.9) persists after extubation. This can readily occur, as most NMBAs have much longer recovery times than the often short-acting opioids and hypnotics used during general anesthesia. In addition, it is impossible to predict recovery of NMB with pharmacologic (PKPD) reasoning, as recovery times of NMBAs display a wide inter-individual variation $^{32,33}$.

Residual curarization negatively affects pulmonary and upper airway muscle function. It promotes upper airway collapse and ventilatory compromise. This is relevant, as even a small degree of residual curarization (e.g. TOF ratio between 0.6 and 0.9 ) is associated with increased upper airway collapsibility and dysfunction of pharyngeal and upper esophageal sphincter muscles ${ }^{23,27}$. Additionally, NMBAs directly attenuate the hypoxic ventilatory response due to blocking of nicotinergic acetylcholine receptors in the carotid bodies ${ }^{24}$. Inhibition of the hypoxic ventilatory response renders patients at increased risk for hypoxia. Owing to these effects, PORC is highly associated with postoperative respiratory complications ${ }^{3,30}$. Unfortunately, incidences of PORC are substantial and range between 20 and $60 \%$ of patients in the post-anesthesia care unit (PACU) $)^{31,34,35}$. Use of a neuromuscular monitor and adequate reversal of NMB are essential strategies that will reduce the incidence of PORC.

\section{Prevention of postoperative residual curarization}

With the use of neostigmine and other acetylcholinesterase inhibitors, a variable degree of residual $\mathrm{NMB}$ often persists ${ }^{36}$. It is therefore not surprising that the effect of NMB reversal with neostigmine on postoperative respiratory complications and outcome is, at best, ambiguous. Increasing evidence shows that NMB reversal with neostigmine (without the guidance of a TOF watch) does not improve postoperative respiratory safety ${ }^{37}$ and may even be associated with increased rates of atelectasis ${ }^{38}$, hypoxemia $^{39}$, and, consequently, reintubation ${ }^{40}$. There are several explanations for these findings. Timely administration and exclusive reversal of a moderate NMB are important for successful reversal. Evidently, this requires adequate neuromuscular monitoring. In addition, time to full reversal following neostigmine treatment displays wide between-patient variations and is unpredictable. Sugammadex has the potential to do better in both respects, as it allows for fast, complete, and predictable reversal of both moderate and deep $\mathrm{NMB}^{15,16,41,42}$. Emerging evidence shows that NMB reversal with sugammadex reduces the rate of postoperative residual curarization compared to reversal with neostigmine (see Table 1) ${ }^{36,39,43}$. A recent investigation reported a $0 \%$ PORC rate in patients reversed with sugammadex versus $46 \%$ in those who received neostigmine ${ }^{43}$. These results are promising; however, in an unmonitored setting, PORC after sugammadex reversal still occurred in $4 \%$ of patients ${ }^{36,39,44}$. This highlights the need for adequate neuromuscular monitoring in any setting where NMBAs are used, regardless of the type of reversal agent.

We argue that NMB reversal with sugammadex will decrease the incidence of postoperative pulmonary complications by causing complete recovery of ventilatory muscle strength. This was shown in two studies in healthy volunteers. Sugammadex reversal led to a higher degree of diaphragmatic and intercostal muscle activation and higher arterial $\mathrm{pO}_{2}$ values compared to neostigmine reversal ${ }^{45,46}$. In addition, it is likely that sugammadex will allow for a better return of the hypoxic ventilatory drive, which is attenuated at very low levels of residual neuromuscular block ${ }^{24}$. Especially in vulnerable patients, such as the obese and elderly, full recovery of the ventilatory muscles and hypoxic ventilatory reflex is crucial to prevent pulmonary complications. Initial evidence from a retrospective study shows that sugammadex reversal was associated with reduced incidence of pulmonary complications in elderly ASA three and four patients compared to reversal with neostigmine ${ }^{47}$. In a small prospective study, sugammadex reversal was associated with fewer hypoxemic events in the PACU compared to neostigmine

Table 1. Studies comparing sugammadex and neostigmine on incidence of postoperative residual curarization and pulmonary outcome.

\begin{tabular}{|l|l|l|l|l|l|l|}
\hline Author & Year & Design & Comparison & Monitoring & PORC & Pulmonary outcome \\
\hline Kotake $^{44}$ & 2013 & $\begin{array}{l}\text { Prospective } \\
\text { observational }\end{array}$ & $\begin{array}{l}\text { Sugammadex versus } \\
\text { neostigmine }\end{array}$ & No & $4.3 \%$ versus 23.9\%** & UA \\
\hline Ledowski ${ }^{47}$ & 2014 & $\begin{array}{l}\text { Retrospective } \\
\text { cohort }\end{array}$ & $\begin{array}{l}\text { Sugammadex versus } \\
\text { neostigmine }\end{array}$ & Available & UA & $\begin{array}{l}\text { Reduced pulmonary } \\
\text { outcome score in ASA } \\
3-4 \text { patients }\end{array}$ \\
\hline Brueckmann & 2015 & RCT & $\begin{array}{l}\text { Sugammadex versus } \\
\text { neostigmine }\end{array}$ & Available & 0\% versus 43.3\%** & $\begin{array}{l}\text { Respiratory disorders: } \\
1.4 \% \text { versus } 6.5 \% \#\end{array}$ \\
\hline Boon $^{39}$ & 2016 & RCT & $\begin{array}{l}\text { Sugammadex versus } \\
\text { neostigmine }\end{array}$ & No & $4 \%$ versus $70 \%{ }^{* *}$ & $\begin{array}{l}\text { Lowest } \mathrm{O}_{2} \text { saturation: } \\
\text { versus } 2.6 \%\end{array}$ \\
\hline Nemes $^{36}$ & 2017 & RCT & $\begin{array}{l}\text { Sugammadex versus } \\
\text { neostigmine }\end{array}$ & No & $3.7 \%$ versus $15.4 \% \#$ & UA \\
\hline
\end{tabular}

ASA, American Society of Anesthesiologists; PORC, postoperative residual curarization (train of four [TOF] ratio <0.9 after extubation); RCT, randomized controlled trial; $\mathrm{UA}$, unavailable.

${ }^{*} p<0.05$

${ }^{* *} p<0.001$

$\# p>0.05$ 
reversal $^{39}$. The current evidence is far from complete, and future prospective studies should determine the exact value of sugammadex in improving post-anesthesia pulmonary outcome.

\section{Deep neuromuscular block: prevention of diaphragmatic contractions and optimized surgical conditions}

The most important advantages of a deep NMB over a moderate block are the full relaxation of the abdominal wall musculature and diaphragm. This results in a significant improvement in surgical conditions, especially of procedures confined to a narrow space, such as laparoscopic surgery. Both abdominal wall muscles and the diaphragm are more resistant to NMBAs compared to the reference muscle musculus adductor pollicis ${ }^{48-50}$. A deep NMB is required to fully relax these muscle groups. For example, Fernando and colleagues showed that a deep NMB is required to silence the diaphragm in response to stimulation of the carina ${ }^{48}$. Similarly, Werba and colleagues showed that diaphragmatic responses evoked by tracheal suctioning led to coughing, bucking, and elevated intracranial pressures in neurosurgical patients, unless deep NMB was applied ${ }^{49}$. In addition, during laparoscopic surgery, efferent activation of the diaphragm from brainstem chemosensitive respiratory centers may occur as a result of elevated arterial $\mathrm{pCO}_{2}$ levels (due to $\mathrm{CO}_{2}$ insufflation). Only in deep NMB are these diaphragmatic contractions effectively prevented.

Martini et al. assessed the effect of deep versus moderate NMB on surgical conditions during laparoscopic retroperitoneal urologic surgery ${ }^{19}$. They developed the validated five-point Leiden surgical rating scale (L-SRS, 0-5; extremely poor to optimal working conditions) to quantify the quality of the surgical field as experienced by the surgeon at various points during the procedure ${ }^{19,20,51}$. The study showed an improvement of 0.7 L-SRS points (mean L-SRS 4.0 versus 4.7 ) when deep NMB was applied, an improvement deemed clinically significant by the surgical team ${ }^{19}$. In many other procedures, a similar effect of deep NMB was found ${ }^{18,20,21,52-54}$, but it is important to acknowledge that some studies found no effect of deep NMB on surgical conditions (see Table 2) ${ }^{55}$. A recent meta-analysis confirmed the positive effect of a deep NMB on surgical conditions and reduced postoperative pain scores; however, significant heterogeneity between the included studies reduces the overall quality of evidence $^{56}$. It is important to realize that other factors such as deep anesthesia may positively affect surgical working conditions. However, deep anesthesia, although applicable, is associated with less hemodynamic stability and prolonged recovery times.

Adversaries of deep NMB claim that the gains in surgical conditions with deep NMB are modest at best and are not worth the extra effort and cost of the reversal agents (sugammadex) ${ }^{57,58}$. We argue that the observed differences in L-SRS are clinically relevant, the incidence of suboptimal conditions is greatly reduced during deep NMB (especially the occurrence of sudden diaphragmatic contractions) $)^{18-20,52}$, and, most important, deep NMB is associated with less postoperative pain and a lesser incidence of unplanned 30-day readmission ${ }^{20,59}$.

Finally, there are indications that a deep NMB allows for lower intra-abdominal pressure during laparoscopic surgery. Reduced insufflation pressure is associated with less postoperative pain $^{60}$. Deep NMB might cause an increase in abdominal wall compliance and consequently an increase in intra-abdominal space $^{61,62}$. However, while various studies indeed show that deep NMB allows titration to lower intra-abdominal pressures with

Table 2. Studies assessing deep NMB on surgical conditions during open and laparoscopic surgery (normal pressure pneumoperitoneum).

\begin{tabular}{|c|c|c|c|c|c|c|}
\hline Author & Specialty & Control & Intervention & Scale & Mean score & $\begin{array}{l}\% \text { unacceptable } \\
\text { surgical conditions }\end{array}$ \\
\hline Martini $^{19}$ & $\begin{array}{l}\text { Urology } \\
\text { (laparoscopy) }\end{array}$ & Moderate NMB & Deep NMB & L-SRS & 4.0 versus $4.7^{* *}$ & $18 \%$ versus $1 \%$ \\
\hline $\mathrm{YoO}^{21}$ & $\begin{array}{l}\text { Urology } \\
\text { (laparoscopy) }\end{array}$ & Moderate NMB & Deep NMB & L-SRS & 3.0 versus $4.0^{* *}$ & UA \\
\hline Boon $^{52}$ & $\begin{array}{l}\text { Urology } \\
\text { (laparoscopy) }\end{array}$ & $\begin{array}{l}\text { Deep NMB + } \\
\text { hypercapnia }\end{array}$ & $\begin{array}{l}\text { Deep NMB + } \\
\text { hypocapnia }\end{array}$ & L-SRS & 4.84 versus $4.77 \#$ & 1 versus $1 \%$ \\
\hline Torensma 20 & $\begin{array}{l}\text { Bariatric surgery } \\
\text { (laparoscopy) }\end{array}$ & Moderate NMB & Deep NMB & L-SRS & 4.2 versus $4.8^{\star *}$ & UA \\
\hline Baete $^{55}$ & $\begin{array}{l}\text { Bariatric surgery } \\
\text { (laparoscopy) }\end{array}$ & Moderate NMB & Deep NMB & L-SRS & 4.1 versus $3.9 \#$ & UA \\
\hline Madsen $^{62}$ & $\begin{array}{l}\text { Gynecology } \\
\text { (laparoscopy) }\end{array}$ & No NMB & Deep NMB & $\begin{array}{l}1 \text { (optimal) - } \\
4 \text { (unacceptable) }\end{array}$ & 1.7 versus $1.0^{*}$ & UA \\
\hline Blobner $^{18}$ & $\begin{array}{l}\text { General surgery } \\
\text { (laparoscopy) }\end{array}$ & No NMB & Deep NMB & $\begin{array}{l}0 \text { (not acceptable) - } \\
100 \text { (excellent) }\end{array}$ & UA & 0 versus $28 \%$ * \\
\hline Rosenberg ${ }^{54}$ & $\begin{array}{l}\text { General surgery } \\
\text { (laparoscopy) }\end{array}$ & Moderate NMB & Deep NMB & $\begin{array}{l}0 \text { (poor) - } \\
10 \text { (excellent) }\end{array}$ & 6.8 versus $7.9^{*}$ & UA \\
\hline Madsen $^{53}$ & $\begin{array}{l}\text { General surgery } \\
\text { (laparotomy) }\end{array}$ & Moderate NMB & Deep NMB & L-SRS & 4.0 versus $4.75^{\star *}$ & 17 versus $49 \%$ ** \\
\hline
\end{tabular}


still-acceptable surgical conditions, the gain in intra-abdominal space may be marginal ${ }^{62}$, and the incidence of unacceptable surgical conditions remained substantially higher than under standard pressures. Hence, the feasibility of low-pressure pneumoperitoneum needs further investigation.

\section{Conclusions}

NMBAs certainly have important advantages but also serious disadvantages. Postoperative residual curarization is an important threat, especially in patients who are not adequately reversed or monitored. An important new development is the introduction of the reversal agent sugammadex. Sugammadex may help reduce the incidence of postoperative residual curarization and improve postoperative respiratory recovery. In addition, sugammadex enables the use of a deep NMB during general anesthesia. While the deep NMB has been shown to improve surgical conditions and reduce postoperative pain in a variety of procedures, its place in anesthesia is not yet fully determined.

\section{Competing interests}

$\mathrm{MB}, \mathrm{CHM}$, and $\mathrm{AD}$ received speaker and/or consultancy fees from Merck Sharp \& Dohme Corporation, The Netherlands BV. The laboratory of professor Dahan received grants from Merck Sharp \& Dohme Corporation BV to support investigator initiated trials.

\section{Grant information}

The author(s) declared that no grants were involved in supporting this work.
1. GRIFFITH HR, JOHNSON GE: THE USE OF CURARE IN GENERAL ANESTHESIA. Anesthesiology. 1942; 3: 418-20.

Publisher Full Text

2. GRAY TC, REES GJ: The role of apnoea in anaesthesia for major surgery. $B$ Med J. 1952; 2(4790): 891-2.

PubMed Abstract | Publisher Full Text | Free Full Text

3. Berg H, Roed J, Viby-Mogensen J, et al:: Residual neuromuscular block is a risk factor for postoperative pulmonary complications. A prospective, randomised, and blinded study of postoperative pulmonary complications after atracurium, vecuronium and pancuronium. Acta Anaesthesiol Scand. 1997; 41(9): 1095-103. PubMed Abstract | Publisher Full Text

4. F BEECHER HK, TODD DP: A study of the deaths associated with anesthesia and surgery: based on a study of 599, 548 anesthesias in ten institutions 1948-1952, inclusive. Ann Surg. 1954; 140(1): 2-35. PubMed Abstract | Free Full Text | F1000 Recommendation

5. F Grosse-Sundrup M, Henneman JP, Sandberg WS, et al:: Intermediate acting non-depolarizing neuromuscular blocking agents and risk of postoperative respiratory complications: prospective propensity score matched cohort study. BMJ. 2012; 345: e6329.

PubMed Abstract | Publisher Full Text | Free Full Text | F1000 Recommendation

6. Harrison GG: Death attributable to anaesthesia. A 10-year survey (1967--1976). Br J Anaesth. 1978; 50(10): 1041-6.

PubMed Abstract | Publisher Full Text

7. Bom A, Bradley M, Cameron $\mathrm{K}$, et al.: A novel concept of reversing neuromuscular block: chemical encapsulation of rocuronium bromide by a cyclodextrin-based synthetic host. Angew Chem Int Ed Engl. 2002; 41(2): $266-70$

PubMed Abstract | Publisher Full Text

8. Welliver M, McDonough J, Kalynych N, et al: Discovery, development, and clinical application of sugammadex sodium, a selective relaxant binding agent. Drug Des Devel Ther. 2009; 2: 49-59.

PubMed Abstract | Publisher Full Text | Free Full Text

9. Sorgenfrei IF, Norrild K, Larsen PB, et al:: Reversal of rocuronium-induced neuromuscular block by the selective relaxant binding agent sugammadex: dose-finding and safety study. Anesthesiology. 2006; 104(4): 667-74. PubMed Abstract

10. Suy K, Morias K, Cammu G, et al:: Effective reversal of moderate rocuroniumor vecuronium-induced neuromuscular block with sugammadex, a selective relaxant binding agent. Anesthesiology. 2007; 106(2): 283-8. PubMed Abstract | Publisher Full Text

11. F Pühringer FK, Rex C, Sielenkämper AW, et al:: Reversal of profound, highdose rocuronium-induced neuromuscular blockade by sugammadex at two different time points: an international, multicenter, randomized, dose-finding, safety assessor-blinded, phase II trial. Anesthesiology. 2008; 109(2): 188-97. PubMed Abstract | Publisher Full Text | F1000 Recommendation

12. Rex C, Wagner S, Spies $\mathrm{C}$, et al.: Reversal of neuromuscular blockade by sugammadex after continuous infusion of rocuronium in patients randomized to sevoflurane or propofol maintenance anesthesia. Anesthesiology. 2009; 111(1): 30-5.

PubMed Abstract | Publisher Full Text

13. de Boer HD, Driessen JJ, Marcus MA, et al.: Reversal of rocuronium-induced
(1.2 $\mathrm{mg} / \mathrm{kg}$ ) profound neuromuscular block by sugammadex: a multicenter, dose-finding and safety study. Anesthesiology. 2007; 107(2): 239-44. PubMed Abstract | Publisher Full Text

14. Sacan $O$, White PF, Tufanogullari B, et al:: Sugammadex reversal of rocuroniuminduced neuromuscular blockade: a comparison with neostigmineglycopyrrolate and edrophonium-atropine. Anesth Analg. 2007; 104(3): 569-74 PubMed Abstract | Publisher Full Text

15. Khuenl-Brady KS, Wattwil M, Vanacker BF, et al.: Sugammadex provides faster reversal of vecuronium-induced neuromuscular blockade compared with neostigmine: a multicenter, randomized, controlled trial. Anesth Analg. 2010; 110(1): 64-73.

PubMed Abstract | Publisher Full Text

16. Duvaldestin $\mathrm{P}$, Kuizenga $\mathrm{K}$, Saldien $\mathrm{V}$, et al.: A randomized, dose-response study of sugammadex given for the reversal of deep rocuronium- or vecuroniuminduced neuromuscular blockade under sevoflurane anesthesia. Anesth Analg. 2010; 110(1): 74-82.

PubMed Abstract | Publisher Full Text

17. F Haerter F, Simons JC, Foerster U, et al.: Comparative Effectiveness of Calabadion and Sugammadex to Reverse Non-depolarizing Neuromuscularblocking Agents. Anesthesiology. 2015; 123(6): 1337-49.

PubMed Abstract | Publisher Full Text | Free Full Text | F1000 Recommendation

18. F Blobner M, Frick CG, Stäuble RB, et al:: Neuromuscular blockade improves surgical conditions (NISCO). Surg Endosc. 2015; 29(3): 627-36.

PubMed Abstract | Publisher Full Text | F1000 Recommendation

19. Martini $\mathrm{CH}$, Boon M, Bevers RF, et al:: Evaluation of surgical conditions during laparoscopic surgery in patients with moderate vs deep neuromuscular block. Br J Anaesth. 2014; 112(3): 498-505. PubMed Abstract | Publisher Full Text

20. Torensma B, Martini $\mathrm{CH}$, Boon M, et al:: Deep Neuromuscular Block Improves Surgical Conditions during Bariatric Surgery and Reduces Postoperative Pain: A Randomized Double Blind Controlled Trial. PLoS One. 2016; 11(12): e0167907.

PubMed Abstract | Publisher Full Text | Free Full Text

21. F Yoo YC, Kim NY, Shin S, et al:: The Intraocular Pressure under Deep versus Moderate Neuromuscular Blockade during Low-Pressure Robot Assisted Laparoscopic Radical Prostatectomy in a Randomized Trial. PLoS One. 2015; 10(8): e0135412.

PubMed Abstract | Publisher Full Text | Free Full Text | F1000 Recommendation

22. Ali HH, Utting JE, Nightingale DA, et al:: Quantitative assessment of residual curarization in humans. Br J Anaesth. 1970; 42(9): 802-3. PubMed Abstract

23. Eriksson LI, Sundman $\mathrm{E}$, Olsson $\mathrm{R}$, et al: Functional assessment of the pharynx at rest and during swallowing in partially paralyzed humans: simultaneous videomanometry and mechanomyography of awake human volunteers. Anesthesiology. 1997; 87(5): 1035-43. PubMed Abstract

24. Eriksson LI, Lennmarken $\mathrm{C}$, Wyon $\mathrm{N}$, et al.: Attenuated ventilatory response to hypoxaemia at vecuronium-induced partial neuromuscular block. Acta Anaesthesiol Scand. 1992; 36(7): 710-5. PubMed Abstract | Publisher Full Text

25. Eikermann $\mathrm{M}$, Groeben $\mathrm{H}$, Hüsing J, et al.: Accelerometry of adductor pollicis 
muscle predicts recovery of respiratory function from neuromuscular blockade. Anesthesiology. 2003; 98(6): 1333-7.

PubMed Abstract | Publisher Full Text

26. Eikermann $\mathrm{M}$, Blobner $\mathrm{M}$, Groeben $\mathrm{H}$, et al.: Postoperative upper airway obstruction after recovery of the train of four ratio of the adductor pollicis muscle from neuromuscular blockade. Anesth Analg. 2006; 102(3): 937-42. PubMed Abstract | Publisher Full Text

27. Sundman $\mathrm{E}$, Witt $\mathrm{H}$, Olsson $\mathrm{R}$, et al:: The incidence and mechanisms of pharyngeal and upper esophageal dysfunction in partially paralyzed humans: pharyngeal videoradiography and simultaneous manometry after atracurium. Anesthesiology. 2000; 92(4): 977-84.

PubMed Abstract | Publisher Full Text

28. Viby-Mogensen J, Howardy-Hansen P, Chraemmer-Jørgensen B, et al.: Posttetanic count (PTC): a new method of evaluating an intense nondepolarizing neuromuscular blockade. Anesthesiology. 1981; 55(4): 458-61. PubMed Abstract

29. Fuchs-Buder T, Claudius C, Skovgaard LT, et al:: Good clinical research practice in pharmacodynamic studies of neuromuscular blocking agents II: the Stockholm revision. Acta Anaesthesiol Scand. 2007; 51(7): 789-808. PubMed Abstract | Publisher Full Text

30. F Murphy GS, Szokol JW, Marymont JH, et al:: Residual neuromuscular blockade and critical respiratory events in the postanesthesia care unit. Anesth Analg. 2008; 107(1): 130-7. PubMed Abstract | Publisher Full Text | F1000 Recommendation

31. F Murphy GS, Szokol JW, Avram MJ, et al.: Residual Neuromuscular Block in the Elderly: Incidence and Clinical Implications. Anesthesiology. 2015; 123(6): 1322-36.

PubMed Abstract | Publisher Full Text | F1000 Recommendation

32. Debaene B, Plaud B, Dilly MP, et al.: Residual paralysis in the PACU after a single intubating dose of nondepolarizing muscle relaxant with an intermediate duration of action. Anesthesiology. 2003; 98(5): 1042-8. PubMed Abstract | Publisher Full Text

33. Katz RL: Neuromuscular effects of d-tubocurarine, edrophonium and neostigmine in man. Anesthesiology. 1967; 28(2): 327-36. PubMed Abstract

34. F Fortier L, McKeen D, Turner K, et al:: The RECITE Study: A Canadian Prospective, Multicenter Study of the Incidence and Severity of Residual Neuromuscular Blockade. Anesth Analg. 2015; 121(2): 366-72. PubMed Abstract | Publisher Full Text | F1000 Recommendation

35. Murphy GS, Brull SJ: Residual neuromuscular block: lessons unlearned. Part I: definitions, incidence, and adverse physiologic effects of residual neuromuscular block. Anesth Analg. 2010; 111(1): 120-8. PubMed Abstract | Publisher Full Text

36. F Nemes R, Fülesdi B, Pongrácz A, et al:: Impact of reversal strategies on the incidence of postoperative residual paralysis after rocuronium relaxation without neuromuscular monitoring: A partially randomised placebo controlled trial. Eur J Anaesthesiol. 2017; 34(9): 609-16.

PubMed Abstract | Publisher Full Text | F1000 Recommendation

37. Meyer MJ, Bateman BT, Kurth T, et al:: Neostigmine reversal doesn't improve postoperative respiratory safety. BMJ. 2013; 346 : f1460. PubMed Abstract | Publisher Full Text | Free Full Text

38. F Herbstreit F, Zigrahn D, Ochterbeck C, et al:: Neostigmine/glycopyrrolate administered after recovery from neuromuscular block increases upper airway collapsibility by decreasing genioglossus muscle activity in response to negative pharyngeal pressure. Anesthesiology. 2010; 113(6): 1280-8. PubMed Abstract | Publisher Full Text | F1000 Recommendation

39. Boon M, Martini C, Broens S, et al:: Improved postoperative oxygenation after antagonism of moderate neuromuscular block with sugammadex versus neostigmine after extubation in 'blinded' conditions. Br J Anaesth. 2016; 117(3): 410-1.

PubMed Abstract | Publisher Full Text

40. Sasaki N, Meyer MJ, Malviya SA, et al:: Effects of neostigmine reversal of nondepolarizing neuromuscular blocking agents on postoperative respiratory outcomes: a prospective study. Anesthesiology. 2014; 121(5): 959-68. PubMed Abstract | Publisher Full Text

41. Lee C, Jahr JS, Candiotti KA, et al.: Reversal of profound neuromuscular block by sugammadex administered three minutes after rocuronium: a comparison with spontaneous recovery from succinylcholine. Anesthesiology. 2009; 110(5) $1020-5$.

PubMed Abstract | Publisher Full Text

42. Blobner M, Eriksson LI, Scholz J, et al.: Reversal of rocuronium-induced neuromuscular blockade with sugammadex compared with neostigmine during sevoflurane anaesthesia: results of a randomised, controlled trial. Eur $J$ Anaesthesiol. 2010; 27(10): 874-81.

PubMed Abstract | Publisher Full Tex

43. F Brueckmann B, Sasaki N, Grobara P, et al.: Effects of sugammadex on incidence of postoperative residual neuromuscular blockade: a randomized, controlled study. Br J Anaesth. 2015; 115(5): 743-51.

PubMed Abstract | Publisher Full Text | F1000 Recommendation

44. $\mathrm{F}$ Kotake $\mathrm{Y}$, Ochiai $\mathrm{R}$, Suzuki $\mathrm{T}$, et al:: Reversal with sugammadex in the absence of monitoring did not preclude residual neuromuscular block. Anesth Analg. 2013; 117(2): 345-51.

PubMed Abstract | Publisher Full Text | F1000 Recommendation

45. F Schepens T, Cammu G, Saldien V, et al:: Electromyographic activity of the diaphragm during neostigmine or sugammadex-enhanced recovery after neuromuscular blockade with rocuronium: a randomised controlled study in healthy volunteers. Eur J Anaesthesiol. 2015; 32(1): 49-57.

PubMed Abstract | Publisher Full Text | F1000 Recommendation

46. F Cammu G, Schepens $\mathrm{T}$, de Neve N, et al.: Diaphragmatic and intercostal electromyographic activity during neostigmine, sugammadex and neostigmine-sugammadex-enhanced recovery after neuromuscular blockade: A randomised controlled volunteer study. Eur J Anaesthesiol. 2017; 34(1): 8-15. PubMed Abstract | Publisher Full Text | F1000 Recommendation

47. Ledowski T, Falke L, Johnston F, et al:: Retrospective investigation of postoperative outcome after reversal of residual neuromuscular blockade: sugammadex, neostigmine or no reversal. Eur J Anaesthesiol. 2014; 31(8): $423-9$

PubMed Abstract | Publisher Full Tex

48. Fernando PU, Viby-Mogensen J, Bonsu AK, et al: Relationship between posttetanic count and response to carinal stimulation during vecuroniuminduced neuromuscular blockade. Acta Anaesthesiol Scand. 1987; 31(7): 593-6. PubMed Abstract | Publisher Full Text

49. Werba A, Klezl M, Schramm W, et al.: The level of neuromuscular block needed to suppress diaphragmatic movement during tracheal suction in patients with raised intracranial pressure: a study with vecuronium and atracurium Anaesthesia. 1993; 48(4): 301-3. PubMed Abstract | Publisher Full Text

50. Donati F, Antzaka C, Bevan DR: Potency of pancuronium at the diaphragm and the adductor pollicis muscle in humans. Anesthesiology. 1986; 65(1): 1-5. PubMed Abstract | Publisher Full Text

51. Nervil GG, Medici R, Thomsen JLD, et al:: Validation of subjective rating scales for assessment of surgical workspace during laparoscopy. Acta Anaesthesiol Scand. 2017; 61(10): 1270-7.

PubMed Abstract | Publisher Full Text

52. Boon M, Martini C, Hellinga M, et al:: Influence of variations in arterial PCO2 on surgical conditions during laparoscopic retroperitoneal surgery. $\mathrm{Br} J$ Anaesth. 2016; 117(1): 59-65.

PubMed Abstract | Publisher Full Text | Free Full Text

53. F Madsen MV, Scheppan S, Mørk E, et al:: Influence of deep neuromuscular block on the surgeonś assessment of surgical conditions during laparotomy: a randomized controlled double blinded trial with rocuronium and sugammadex. Br J Anaesth. 2017; 119(3): 435-42.

PubMed Abstract | Publisher Full Text | F1000 Recommendation

54. F Rosenberg J, Herring WJ, Blobner M, et al:: Deep Neuromuscular Blockade mproves Laparoscopic Surgical Conditions: A Randomized, Controlled Study. Adv Ther. 2017; 34(4): 925-36.

PubMed Abstract | Publisher Full Text | F1000 Recommendation

55. F Baete S, Vercruysse G, Vander Laenen M, et al:: The Effect of Deep Versus Moderate Neuromuscular Block on Surgical Conditions and Postoperative Respiratory Function in Bariatric Laparoscopic Surgery: A Randomized, Double Blind Clinical Trial. Anesth Analg. 2017; 124(5): 1469-75. PubMed Abstract | Publisher Full Text | F1000 Recommendation

56. Bruintjes $\mathrm{MH}$, van Helden $\mathrm{EV}$, Braat $\mathrm{AE}$, et al: Deep neuromuscular block to optimize surgical space conditions during laparoscopic surgery: a systematic review and meta-analysis. Br J Anaesth. 2017; 118(6): 834-42. PubMed Abstract | Publisher Full Text

57. Kopman AF, Naguib M: Laparoscopic surgery and muscle relaxants: is deep block helpful? Anesth Analg. 2015; 120(1): 51-8. PubMed Abstract | Publisher Full Text

58. Kopman AF, Naguib M: Is deep neuromuscular block beneficial in laparoscopic surgery? No, probably not. Acta Anaesthesiol Scand. 2016; 60(6): 717-22. PubMed Abstract | Publisher Full Text

59. Christian M, Martijn B, Keri Y, et al:: A Retrospective Study on the Effect of Deep Neuromuscular Block on Healthcare Resource Utilization. Abstract A1025, in Annual meeting of the American Society of Anesthesiology. 2017. Reference Source

60. Sarli L, Costi R, Sansebastiano G, et al.: Prospective randomized trial of lowpressure pneumoperitoneum for reduction of shoulder-tip pain following laparoscopy. Br J Surg. 2000; 87(9): 1161-5. PubMed Abstract

61. F Barrio J, Errando CL, San Miguel G, et al:: Effect of depth of neuromuscula blockade on the abdominal space during pneumoperitoneum establishment in laparoscopic surgery. J Clin Anesth. 2016; 34: 197-203. PubMed Abstract | Publisher Full Text | F1000 Recommendation

62. F Madsen MV, Gätke MR, Springborg HH, et al.: Optimising abdominal space with deep neuromuscular blockade in gynaecologic laparoscopy--a randomised, blinded crossover study. Acta Anaesthesiol Scand. 2015; 59(4): $441-7$

PubMed Abstract | Publisher Full Text | F1000 Recommendation 


\section{Open Peer Review}

\section{Current Peer Review Status:}

\section{Editorial Note on the Review Process}

Faculty Reviews are review articles written by the prestigious Members of Faculty Opinions. The articles are commissioned and peer reviewed before publication to ensure that the final, published version is comprehensive and accessible. The reviewers who approved the final version are listed with their names and affiliations.

\section{The reviewers who approved this article are:}

\section{Version 1}

\section{Ahmed R Ahmed}

Department of Bariatric and Metabolic Surgery, Imperial College London, London, UK Competing Interests: Dr Ahmed receives speaker honoraria from Merck Sharp \& Dohme Corporation (MSD).

\section{Jacob Rosenberg} Department of Surgery, Herlev Hospital, University of Copenhagen, Herlev, Denmark

Competing Interests: Dr. Rosenberg reports personal fees from Bard and personal fees from Merck, outside the submitted work.

\section{Peter Biro}

Department of Anesthesiology, University Hospital Zurich, Zurich, Switzerland

Competing Interests: No competing interests were disclosed.

\section{Thomas Mencke}

Department of Anesthesia and Intensive Care Medicine, University of Rostock, Rostock, Germany

Competing Interests: No competing interests were disclosed. 
The benefits of publishing with F1000Research:

- Your article is published within days, with no editorial bias

- You can publish traditional articles, null/negative results, case reports, data notes and more

- The peer review process is transparent and collaborative

- Your article is indexed in PubMed after passing peer review

- Dedicated customer support at every stage

For pre-submission enquiries, contact research@f1000.com 